\title{
Quality of Communication Life in Prelingually Deafened Adults with Cochlear Implant
}

\author{
Seul-Gi Lee ${ }^{\mathrm{a}}$, Sang-Im Jung ${ }^{\mathrm{b}}$, Pyung-Kon Tark ${ }^{\mathrm{b}}$, Soo-Bok Lee ${ }^{\mathrm{b}}$, Youngmee Lee \\ ${ }^{a}$ Dong-A Auditory Habilitation Center, Busan, Korea \\ ${ }^{b}$ Department of Speech-Language Therapy \& Aural Rehabilitation, Woosong University, Daejeon, Korea \\ 'Department of Communication Disorders, Tongmyong University, Busan, Korea
}

\author{
Correspondence: Soo-Bok Lee, $\mathrm{PhD}$ \\ Department of Speech-Language Therapy \& Aural \\ Rehabilitation, Woosong University, 171 \\ Dongdaejeon-ro, Dong-gu, Daejeon 34606, Korea \\ Tel: +82-42-630-9222 \\ Fax: +82-42-630-9229 \\ E-mail: nosamor1@gmail.com
}

Received: April 26, 2018

Revised: May 24, 2018

Accepted: June 15, 2018

This paper was summarized from the master's thesis of the first author (2018)
Objectives: The present study was designed to compare the quality of communication life $(\mathrm{QCL})$ between prelingually deafened adults with cochlear implants $(\mathrm{ACl})$ and adults with normal-hearing $(\mathrm{ANH})$, seeking to determine the relationship between $\mathrm{QCL}$ and communication abilities of $\mathrm{ACl}$ while investigating the predictors of QCL. Methods: The QCL scale of $18 \mathrm{ACl}$ and 18 age-matched $\mathrm{ANH}$ was measured. Communication abilities of $\mathrm{ACl}$, such as listening, receptive vocabulary and articulation were also evaluated. A $t$-test was conducted to examine the differences between the groups according to sub-factors of QCL. Pearson correlation analysis was performed to examine the relationship between the communication ability and $\mathrm{QCL}$ of $\mathrm{ACl}$. Finally, multiple regression analysis was performed to evaluate predictor factors of QCL for $\mathrm{ACl}$. Results: $\mathrm{ACl}$ scored significantly lower than $\mathrm{ANH}$ on the QCL scale. They also showed significantly lower scores among the sub-factors of QCL: communication efficacy, daily life participation, and communication attitude. Among the communication abilities, listening ability (monosyllabic word, bisyllabic word, sentence) and articulation accuracy were correlated with QCL. Also, bisyllabic word listening ability was significantly correlated with QCL, predicting $30.2 \%$ of QCL. Conclusion: The results of this study suggest the need to improve $\mathrm{QCL}$ of $\mathrm{ACl}$ by participating in aural rehabilitation programs and that improving listening ability will have a positive influence on the overall quality of life of adults with cochlear implant.

Keywords: Cochlear implant, Prelingually deafened adult, Quality of communication life, Communication ability
'삶의 질(quality of life, QOL)'이라는 용어는 1960년대 중반 이후 자본주의 국가를 중심으로 사용되기 시작하였고(Lee, 1999), 현재 는 의학, 간호학, 사회복지학 등 다양한 분야에서 성인, 노인, 근로 자와 같은 일반인의 건강 관련 삶의 질이 연구되고 있다(Kim \& Jung, 2014a, 2014b). 특수교육 및 재활 분야에서는 1980년대 후반 부터 장애인 삶의 질에 대한 관심이 높아졌고, 최근에는 의학 및 간 호학 등 다양한 분야에서까지 장애인의 주관적인 삶의 질이 부각 되고 있다(Lee \& Cho, 2011; Park, 2002). 일반적으로 '삶의 질(QOL)' 이란 개인이 살고 있는 문화 및 가치 체계 안에서 자신의 목표, 기 대, 규범, 관심 등과 관련된 스스로의 상태에 대한 개인적인 인식으 로(The WHOQOL Group, 1995), 신체적 기능, 개인의 정서적 상
태, 심리사회적 태도에 대한 주관적인 느낌으로 정의된다(Bose,

McHugh, Schollenberger, \& Buchanan, 2009).

이러한 삶의 질은 타인에게서 자신의 욕구를 이해받고 의사소통 을 시도할 때 적절한 반응을 얻는 사람일수록 높게 나타난다 (Markham, Van Laar, Gibbard, \& Dean, 2009). 의사소통 능력은 사회 적응에 필수적이고 기본적인 능력이기 때문에 의사소통에 관 한 욕구는 개인의 삶에 큰 영향을 미친다(Markham et al., 2009). 청각장애인의 경우에도 마찬가지로 의사소통 능력은 사회적응에 중요한 요소로, 청능재활에서도 청각장애인의 의사소통 능력을 향 상시켜 재활의 궁극적인 목표인 '삶의 질'을 향상시켜야 한다는 생 각이 강조되고 있다(Lee \& Cho, 2011). 그럼에도 다수의 청각장애 
인들은 부족한 의사소통 능력으로 인해 인간관계에서 끊임없이 좌 절을 경험하고, 사회생활에서 많은 제약을 받아 자신에 대한 부정 적인 관점을 갖게 되면서 '삶의 질’도 같이 낮아지는 것이 현실이다 (Clark, 1989; Yoon, 2007). 특히, 선천성 농 청각장애는 태어나면서 부터 박탈된 듣기경험으로 구어 의사소통에 필요한 말.언어 발달 에 부정적인 영향을 미친다. 그들은 비교적 이른 나이에 인공와우 이식을 받고 재활을 받게 되면 말지각뿐 아니라, 언어, 말산출에도 유의한 영향을 미칠 수 있지만(Teoh et al., 2004), 현재의 선천성 농 성인을 보았을 때, 그들은 과거에 다양한 이유로 조기에 수술을 받 지 못하는 경우들이 존재하며, 인공와우를 조기에 수술받아도 이 식 후, 완전히 보상받지 못하는 경우도 존재한다(Heo \& Kim, 2010). 즉, 선천성 농 성인의 구어 의사소통은 인공와우이식 연령, 잔존청 력, 청력박탈기간, 인공와우 사용기간, 듣기능력, 말산출 능력, 어휘 능력, 재활 여부와 같은 요인들이 중요한 역할을 하며, 삶의 질에 영 향을 미칠 것이다.

최근 국내외에서 의사소통 관련 삶의 질(quality of communication life, QCL)을 측정하기 위한 도구가 개발되었고 의사소통장애 가 있는 대상자들을 중점으로 연구들이 진행되어왔다. 국외에서는 Paul 등(2004)이 의사소통장애가 있는 성인의 삶의 질을 살펴보기 위해 QCL을 개발하였으며, 국내에서는 Choi (2011)가 Paul 등(2004) 이 개발한 $\mathrm{QCL}$ 을 한국어로 번안하여 청각장애 청소년을 대상으 로 QCL을 살펴보았다. 그 외 $\operatorname{Kim}$ (2014)의 연구에서는 청각장애아 동들을 대상으로 $\mathrm{QCL}$ 측정 도구를 개발하여 청각장애 아동과 일 반아동의 QCL을 분석하였다. Kim (2017)은 Kim (2014)이 개발한 의사소통 관련 측정 도구를 사용하여 청각장애 중학생을 대상으 로 QCL을 알아보았으며, Kim (2017)에서는 청각장애 대학생을 대 상으로 의사소통 삶의 질을 측정하고, 청각장애 대학생의 의사소 통 능력을 평가하여 의사소통 삶의 질을 예측하는 변인을 분석하 였다. 국내에서 활용되고 있는 Choi (2011)와 Kim (2014)의 QCL은 '의사소통 효능감', '자아존중감 및 사회성', '학교 및 일상생활의 참 여', ‘의사소통 태도', ‘의사소통에 대한 자신감 및 자율성', '역할 및 자아, '일상생활 참여', '타인과의 상호작용' 등의 하위요인들로 구 성되어 있기 때문에 다양한 상황 속에서 QCL을 살펴볼 수 있으나, 각 하위요인에 따른 $\mathrm{QCL}$ 을 살펴보기에 하위유형별 문항의 수가 부족하다.

청년기 이후의 청각장애 성인은 취업 및 진로에 따른 대인관계가 확장되는 시기로 건청인과의 상호작용에서 더 많은 제약이 따르기 때문에, 청각장애 성인의 의사소통 능력은 다른 장애군보다 삶의 질에 더 많은 영향을 미칠 수 있다(Jeong, Lim, \& Kim, 2013). 따라 서 청각장애인들에 대한 교육과 재활은 성인기에 접어들어서도 의
사소통 능력에 초점을 맞추어 이루어져야 하고, 그들의 삶의 질 또 한 의사소통 능력과 관련하여 측정되고 평가되어야 한다(Kim, 2014). 그러나 현재까지 청각장애 성인의 의사소통 수행력에 따른 QCL에 대한 연구는 부족한 실정이다.

본 연구는 인공와우이식 선천성 농 성인의 $\mathrm{QCL}$ 을 측정하고 건청 성인과의 유의미한 차이가 있는지를 살펴보고자 하였다. 이를 위해 $\mathrm{QCL}$ 의 하위유형별(의사소통 효능감, 자아 존중 및 역할, 일상생활 참여, 의사소통 태도)로 집단(인공와우이식 선천성 농 성인, 연령을 일치시킨 건청 성인) 간의 차이가 있는지 알아보고, 의사소통 능력 (단음절 단어검사의 음소점수, 이음절 단어검사의 음소점수, 문장 검사 단어점수, 수용어휘 점수, 조음정확도)과 인공와우이식 선천 성 농 성인의 $\mathrm{QCL}$ 간의 상관관계를 분석하였다. 또한 인공와우이 식 선천성 농 성인의 QCL을 예측할 수 있는 변인들을 살펴보았다.

\section{연구방법}

\section{연구대상}

본 연구는 인공와우이식을 받은 선천성 농 성인 18 명과, 생활연 령을 일치시킨 건청 성인 18 명을 대상으로 진행하였다. 인공와우이 식 선천성 농 성인은 (1) 부산, 대구, 충남지역에 거주하고, (2) 선천 성 농(prelingually deaf)으로, 인공와우이식 수술을 받았으며, (3) 청각장애 이외의 구조적, 기능적 문제 등 중복장애가 없고, (4) 구 어 의사소통이 가능하며, (4) Kim (2008)의 기초학습기능 수행평가 체제: 읽기검사(BASA)를 통해 읽기 능력에 문제가 없는 자를 선정 하였다. 인공와우이식 선천성 농 성인의 정보는 Table 1 과 같다. 연 령 범위는 만 19-39세로 평균 연령 24.55세 $(\mathrm{SD}=4.48)$ 이며, 남자는 6 명, 여자는 12 명이다. 인공와우이식을 받은 시기의 평균 연령은 12.89 세, 인공와우의 평균 사용기간은 11.70 년이며, 모두 청각장애 2급으로 진단받았다.

건청 성인은 인공와우이식 선천성 농 성인과 생활연령을 일치시 킨 평균 연령 24.56 세 $(\mathrm{SD}=3.68)$ 의 정상청력 성인으로 (1) 순음청력 검사 기기(Grason Stadler, GSI-61)를 사용한 검사상 500, 1,000, $2,000 \mathrm{~Hz}$ 에서 $20 \mathrm{~dB} \mathrm{HL}$ 이내로 선별되었고, (2) 말·언어, 학습 관련 하여 확인된 문제가 없는 자로 하였다.

\section{연구도구}

\section{$\mathrm{QCL}$ 문항 구성}

인공와우이식 선천성 농 성인의 의사소통 관련 삶의 질(QCL)을 살펴보기 위해, 기존의 선행연구(Choi, 2011; Kim, 2014; Kim et al., 2014; Lee, 1999; Lee, 2014; Park, 2002; Park, 2015; Paul et al., 2004) 
Table 1. Characteristics of participants: prelingually deafened adults with $\mathrm{Cl}$

\begin{tabular}{|c|c|c|c|c|c|c|}
\hline Case no. & Sex & Age (yr;mo) & Age of surgery (yr;mo) & Terms of $\mathrm{Cl}$ use (yr;mo) & Communication mode & Grade of hearing disorder \\
\hline 1 & $\mathrm{~F}$ & $23 ; 0$ & $18 ; 10$ & $4 ; 1$ & Oral language & 2 \\
\hline 2 & $\mathrm{~F}$ & $20 ; 7$ & $4 ; 2$ & $16 ; 4$ & Oral language & 2 \\
\hline 3 & $\mathrm{~F}$ & $22 ; 8$ & $5 ; 9$ & $16 ; 10$ & Oral language & 2 \\
\hline 4 & $\mathrm{~F}$ & $21 ; 4$ & $8 ; 10$ & $12 ; 6$ & Oral language & 2 \\
\hline 5 & M & $23 ; 4$ & $19 ; 10$ & $3 ; 7$ & Oral language & 2 \\
\hline 6 & $\mathrm{~F}$ & $20 ; 3$ & $4 ; 7$ & $15 ; 8$ & Oral language & 2 \\
\hline 7 & $\mathrm{~F}$ & $23 ; 5$ & $3 ; 10$ & $19 ; 7$ & Oral language & 2 \\
\hline 8 & $\mathrm{~F}$ & $22 ; 11$ & $9 ; 6$ & $13 ; 5$ & Oral language & 2 \\
\hline 9 & M & $23 ; 3$ & $11 ; 8$ & $12 ; 7$ & Oral language & 2 \\
\hline 10 & $\mathrm{~F}$ & $23 ; 9$ & $7 ; 10$ & $16 ; 0$ & Oral language & 2 \\
\hline 11 & $\mathrm{~F}$ & $22 ; 0$ & $7 ; 9$ & $14 ; 2$ & Oral language & 2 \\
\hline 12 & M & $24 ; 10$ & $10 ; 9$ & $13 ; 11$ & Oral language & 2 \\
\hline 13 & M & $24 ; 9$ & $12 ; 6$ & $12 ; 3$ & Oral language & 2 \\
\hline 14 & $\mathrm{~F}$ & $21 ; 3$ & $20 ; 0$ & $1 ; 4$ & Oral language & 2 \\
\hline 15 & $\mathrm{~F}$ & $26 ; 9$ & $15 ; 10$ & $10 ; 11$ & Oral language & 2 \\
\hline 16 & M & $26 ; 0$ & $13 ; 2$ & $12 ; 9$ & Oral language & 2 \\
\hline 17 & $\mathrm{~F}$ & $35 ; 9$ & $31 ; 11$ & $3 ; 9$ & Oral language & 2 \\
\hline 18 & $\mathrm{M}$ & $36 ; 1$ & $25 ; 3$ & $10 ; 11$ & Oral language & 2 \\
\hline
\end{tabular}

$\mathrm{Cl}=$ cochlear implant.

Table 2. Factors of quality of communication life and its components

\begin{tabular}{ll}
\hline Factor & \multicolumn{1}{c}{ Component } \\
\hline Communication efficacy & Confidence and autonomy in communication, communication proficiency, will to challenge \\
Self-esteem and role & Self-esteem, perception of social function and role, establishing relationships \\
Participation in daily life & Participation in conversation, leisure/recreation, interest \\
Communication attitude & Experience, consideration, encouragement, willing to help, kindness, focusing on conversation, effort, ability to react \\
\hline
\end{tabular}

의 설문 문항을 수정 및 재구성하여 사용하였다. 본 연구에서 사용 한 QCL 문항은 1차 예비연구를 바탕으로 4개의 하위요인('의사소 통 효능감' '자아 존중 및 역할', '일상생활 참여', '의사소통 태도') 으로 구성되었고, 예비문항을 추출하였다. 의사소통 관련 삶의 질 의 하위요인과 구성요인은 Table 2와 같다.

4 개의 QCL 하위요인에서 '의사소통 효능감'은 의사소통을 좋아 하고 스스로 의사소통을 잘한다고 느끼는 경향이다(Kim, 2014). '효능감'은 자신이 목표로 하는 것을 획득할 수 있는 신념과 특정한 상황에 대처해나가는 자신의 능력이며(Kim, 2016), 자신감을 가지 고 다양한 생활 속에서 적응하여 주어진 과제를 긍정적으로 해결 할 수 있는 능력이다(Bandura, 1977; Lee, 2014). 즉, '의사소통 효능 감'은 다양한 상황에서 의사소통에 자신감을 가지고 해결할 수 있 는 능력을 말한다. 선행연구에서 '자아 존중 및 역할'은 자기 자신 과 사람들과의 관계에 대해 만족하는 것으로, 학교생활 또는 사회 생활에서 타인과 상호작용 속에서 이루어지는 개인의 역할 및 사회 적 기능이라고 정의한다(Kim, 2014; Kim, 2016; Whyte \& Guiffri- $\mathrm{da}, 2008)$. 즉, '자아 존중 및 역할'은 상호작용 속에서 개인의 역할 과 능력을 말한다. '일상생활 참여'는 다른 사람들과의 상호작용을 경험하는 놀이나 여가활동과 같은 일상생활 등에 참여하는 정도라 고 할 수 있다. ‘의사소통 태도'는 타인과 의사소통 과정에서의 경험 으로, 타인과 의사소통을 할 때 구어 의사소통 상황에 대해 느끼는 감정 및 태도이며(Choi, 2003), 다양한 구어 상황에서 타인과의 대 화 상황에 대처하는 화자의 구어 접근 방식(Park \& Kwon, 2009)이 라고 정의하였다. 즉, 타인과 의사소통을 할 때 '자신의 말과 태도, 대처 능력'을 말한다.

선행연구를 통해 1 차로 구성된 의사소통 관련 삶의 질의 설문 문 항을 본 연구 대상자인 인공와우이식 선천성 농 성인에게 적용시키 기 위해 Park (2012) 연구와 같이, '학교'는 '학교', '직장' 또는 '사회' 로 문항을 수정하였고, 각 문항에 대한 이해도를 높이기 위해 예시 를 추가하는 등의 수정 및 보완을 하였다. 본 연구에 사용될 QCL 도구는 이후에 기술될 타당도, 신뢰도 검증을 수행한 후에 최종 35 개 문항으로 구성하였다(Appendix 1). 


\section{QCL 문항 타당도}

1 차로 구성된 40 개의 설문 문항은 청각장애 언어치료전공 교수 3 인과 10 년 이상 청각장애 언어치료 경험이 있는 전문가 2 인을 통해 하위요인별 문항 구성타당도 및 문장의 명료성에 대한 내용타당도 를 검증하였다. 문항 구성타당도 검증은 5점 척도로 평가하였고, 평정 4 점 이상의 문항만을 선정하였다. 문장의 명료성에 대한 타당 도 검증은 문장의 진술 방식에서 선천성 농 성인이 잘 이해할 수 있 는 문장으로 명료하게 수정되어 있는가에 대한 타당도 검증으로 1 점은 제시된 문장이 청각장애인이 이해하기 어려운 문장임을 의미 하고, 5 점은 청각장애인들이 이해하기에 충분하며 명료하게 기술 되었다는 것을 의미한다. 명료성 검증과정에서는 전문가가 각 문항 에서 3점 이하로 기입했을 경우 이유와 의견을 기재하도록 하였으 며, 연구자는 평정 4 점 미만의 문항에 대해 전문가의 의견을 반영 하여 전공교수 1 인과 검토하여 수정하였다. 1 차 전문가 타당도 검 증 후, 2 차로 인공와우이식 선천성 농 성인 3 인을 대상으로 1 차 전 문가 내용타당도 바탕으로 수정된 문항에 대해 문장 명료성 검증 을 실시하였으며 평정 4점 이상의 문항만을 선정하였다.

청각장애 전문가 집단 5 명에 의해 하위유형별 문항 구성타당도 및 문장의 명료성에 대한 내용타당도를 측정한 결과, 하위유형별 문항 구성타당도의 평균 점수는 4.23점(범위 3.25-4.75, $\mathrm{SD}=.26$ ) 으로 타당한 것으로 나타났다. 전체 문항에서 하위유형별 문항 구 성타당도 점수가 4 점 미만인 문항은 총 5 개로 삭제하였다(예: ‘나는 어려운 과제/일에 도전할 수 있다, '나는 내가 원하는 학교나 직장 을 선택할 수 있다, '나는 내 자신이 좋다', ‘나는 사교활동에 잘 참 여한다', '나는 어려운 친구를 도와줄 수 있다'). 문장 명료성에 대 한 내용타당도를 측정한 결과, 문장 명료성의 평균 점수는 4.14 점 (범위 3.50-4.75, $\mathrm{SD}=.26$ )으로 타당한 것으로 나타났다. 전체 문항 에서 평점 4 점 미만의 문항은 총 4 개로 연구자는 전문가의 의견을 반영하고 전공교수 1 인과 검토하여 문항을 수정하였다. 예를 들어, '나는 친구/친척과 연락하면서 지낸다' 문항을 '나는 친구/친척과 연락(예: 문자, 전화, SNS, 모바일 메신저 등)'으로, '나는 다른 사람 에게 친절하게 대할 수 있다' 문항을 '나는 다른 사람에게 친절하게 대할 수 있다(예: 사람들이 길을 물어볼 때 등)'로 예시를 추가하였 으며, ‘낮선 사람'을 ‘모르는 사람'으로, '타인'을 ‘다른 사람’으로 어 휘에 대한 정의를 내려주는 것이 명료성을 높일 것이라는 전문가 의견을 반영하여 문항을 수정하였다. 수정된 문항은 인공와우이식 선천성 농 성인 3 인을 대상으로 문장 명료성 검증을 실시하였으며 그 결과 평균 점수는 4.68 점(범위 $4-5, \mathrm{SD}=.40$ )으로 타당한 것으로 나타났으며, 모든 문항에서 평균 4 점 이상을 받았다.

구인타당도의 검증은 인공와우이식 선천성 농 성인 18 명에게서
Table 3. Correlations between sub-factors of QCL and total score

\begin{tabular}{|c|c|c|c|c|}
\hline & Total & $\begin{array}{l}\text { Communica- } \\
\text { tion efficacy }\end{array}$ & $\begin{array}{l}\text { Self-esteem } \\
\text { and role }\end{array}$ & $\begin{array}{l}\text { Participation } \\
\text { in daily life }\end{array}$ \\
\hline Communication efficacy & $.790^{* *}$ & & & \\
\hline Self-esteem and role & $.842^{* *}$ & .388 & & \\
\hline Participation in daily life & $.890^{* *}$ & $.572^{*}$ & $.814^{* *}$ & \\
\hline Communication attitude & $.845^{* *}$ & $.747^{*}$ & $.570^{*}$ & $.582^{* *}$ \\
\hline
\end{tabular}

$\mathrm{OCL}=$ quality of communication life.

${ }^{*} p<.05,{ }^{* *} p<.01$.

수집한 QCL 총 점수와, 하위요인별 점수 간 상관분석을 통해 실시 하였다. 각 하위요인과 전체 문항의 총 점수 간 상관계수의 범위는 .790-890으로 유의한 정적 상관관계가 있는 것으로 나타났다. 각 영역 간 상관계수가 다양하게 나타났고 그 중 요인 2 (자아 존중 및 역할)와 요인 3 (일상생활 참여)은 .814로 유의한 상관을 보인 반면 요인 1 (의사소통 효능감)과 요인 2 (자아 존중 및 역할) 간에는 유 의한 상관이 나타나지 않았다(Table 3).

\section{$\mathrm{QCL}$ 문항 신뢰도}

타당도 검증 과정을 통해 구성된 총 35 개의 QCL 문항들의 내적 일관성(internal consistency) 신뢰도 검증을 위해 각 하위요인의 Cronbach's alpha 값을 구하였다. 요인 1 (의사소통 효능감), 요인 2 (자아 존중 및 역할), 요인 3 (일상생활 참여), 요인 4 (의사소통 태 도), 전체 점수의 Cronbach's alpha값은 각각 $.917, .914, .824, .844$ 로 높은 내적일관성이 확인되었다. 대상자가 QCL을 일관성 있게 평가 하였는지를 확인하기 위해 동일한 대상자에게 설문을 두 번 실시 하여 재검사 신뢰도를 산출하였다. 재검사는 첫 평가 이후 2 주의 간 격을 두고 전체의 $20 \%$ 에 해당하는 총 4 명의 대상자를 무작위로 선 정하여 실시한 후, 상관분석을 시행하였다. 그 결과 각 하위요인(의 사소통 효능감, 자아 존중 및 역할, 일상생활 참여, 의사소통 태도) 간의 상관계수는 $.871, .945, .877, .911$ 로 높은 상관관계를 보였다.

\section{연구절차}

인공와우이식 선천성 농 성인의 발화 자료 및 $\mathrm{QCL}$ 수집은 연구 자가 직접 치료실과 병원 등을 방문하여 조용한 장소에서 설문지 의 목적을 충분히 설명하고 실시하였다. 설문검사 진행의 유연함과 정확한 이해를 돕기 위해 피검자가 검사자의 얼굴을 보고 독화를 할 수 있도록 하였고(Yoon, Lee, \& Sim, 2000), 말지각이 어려운 대 상자들에게는 필담을 통해서 내용을 설명하였다. 대상자가 설문지 를 읽고 이해하는 것에 어려움이 없어야 하므로, Kim (2008)의 기 초학습기능 수행평가체제: 읽기검사(BASA)를 통해 읽기능력에 대 한 선별을 실시하였다. 선별을 통과한 대상자의 인구학적 배경변인 
특성을 알아보기 위해 사례 면담지를 제공하여 작성하게 한 후, 5 점 리커트 척도로 이루어진 QCL 설문을 실시하였다. 대상자가 설 문지 작성 중 문항에 대한 설명을 원하는 경우에는 구화 또는 필담 을 통해 충분한 설명을 제공하였다.

대상자의 의사소통 능력 평가는 청각보조기기 상태를 점검한 후, 조용한 방에서 개별적으로 진행되었다. 검사자는 일상 회화 수 준의 강도에서 음성을 제시하였고, 대상자는 검사자가 말한 단어 를 검사자의 입모양을 보지 않고 듣기만으로 따라 말하도록 하였 다. 자극의 제시 횟수는 1 회로 하였고, 대상자가 미처 듣지 못한 경 우이거나 검사자가 잘못 조음한 경우에는 2 회까지 허용하였다. 검 사 문항은 어음청각검사(Korean Speech Audiometry, KSA; Lee et al., 2010)의 일반용(adults) 단음절, 이음절, 문장인지도 검사목록 을 사용하였다. 수용어휘력 평가는 수용-표현어휘력검사(Receptive and Expressive Vocabulary Test, REVT; Kim, Hong, Kim, Jang, \& Lee, 2009)를 사용하였고, 검사지침에 따라 진행하되 말지 각이 어려운 대상자의 경우 해당 그림어휘를 글자로 제시하여 실시 하였다. 조음능력의 경우, 아동용 발음평가(Assessment of Phonology and Articulation for Children, APAC; Kim, Pae, \& Park, 2007)의 단어수준 검사를 사용하여 조음정확도를 산출하였다.

\section{자료분석}

의사소통 관련 삶의 질

QCL은 연구자가 직접 설문지를 채점하여 점수를 산출하였다. 4 가지 하위요인별(의사소통 효능감, 자아 존중 및 역할, 일상생활 참 여, 의사소통 태도)로 평균 점수를 산출하였고, 대상자가 표시한 점 수의 총합을 문항수로 나누어 $\mathrm{QCL}$ 평균 점수를 산출하였다.

\section{듣기능력 과제}

듣기점수 산출은 단음절, 이음절 수준 모두 음소점수로 산출하 였다. 음소점수 산출은 목표단어의 총 음소 개수에서 초성자음, 모 음, 종성자음 중 바르게 따라 말한 음소수를 합하여 평균을 산출 하였다. 문장수준에서는 문장 내 목표단어 총 40 개 중 대상자가 정 확하게 말한 단어수의 평균을 산출하였다.

\section{신뢰도}

조음정확도 신뢰도를 확인하기 위해 연구자 외 언어치료전공 석 사과정생 1 명을 제 2 평가자로 채점과정에 참여시켰다. 조음정확도의 평가자 간 신뢰도를 산출하기 위해 제 2 평가자는 전체 자료의 $20 \%$ (4명)를 무작위로 선정하여 평가한 자료에 대해 피어슨 적률상관 분석을 실시하였고, 평가자 내 신뢰도 분석을 위해 연구자가 조음
정확도 평가로부터 1 주 후에 전체 자료의 $20 \%$ (4명)를 무작위로 선 정하여 평가한 자료에 대해 피어슨 적률상관분석을 실시하였다. 평 가자 내 신뢰도는 .994 ( $p<.001)$, 평가자 간 신뢰도는 .986 ( $p<.001)$ 으로 유의하였다.

\section{통계분석}

자료분석은 SPSS Statistics version 21.0 통계프로그램을 사용하 였다. QCL의 하위요인별(의사소통 효능감, 자아 존중 및 역할, 일 상생활 참여, 의사소통 태도)로 집단(인공와우이식 선천성 농 성인, 연령을 일치시킨 정상청력 성인) 간에 유의한 차이가 있는지를 살 펴보기 위해 $t$-검정을 실시하였고, 의사소통 능력(단음절 단어검사 의 음소점수, 이음절 단어검사의 음소점수, 문장검사 단어점수, 조 음정확도, 수용어휘 점수)과 인공와우이식 선천성 농 성인의 $\mathrm{QCL}$ 의 관계를 살펴보기 위해 피어슨 상관분석을 실시하였다. 마지막으 로, 인공와우이식 선천성 농 성인의 $\mathrm{QCL}$ 을 예측하는 변인과 예측 력을 살펴보기 위해 다중회귀분석을 실시하였다.

\section{연구결과}

\section{$\mathrm{QCL}$ 의 하위요인별 집단 간 차이}

$\mathrm{QCL}$ 의 하위요인별 평균 점수와 전체 평균 점수가 집단 간(인공 와우이식 선천성 농 성인, 생활연령을 일치시킨 건청 성인) 차이가 있는지 알아보기 위해 $t$-검정을 실시하였다. 그 결과, QCL 전체 문 항 점수에서 인공와우이식 선천성 농 성인의 평균은 $3.78(\mathrm{SD}=.46)$, 건청 성인의 평균은 $4.17(\mathrm{SD}=.32)$ 로 인공와우이식 선천성 농 성인 의 점수가 건청 성인 그룹보다 유의하게 낮게 나타났다 $(t=-2.926$, $p<.01)$. 하위요인인 의사소통 효능감에서도 인공와우이식 선천성 농 성인의 점수가 유의하게 낮았고, 일상생활 참여 및 의사소통 태 도 요인에서도 같은 결과가 확인되었다. 자아 존중 및 역할 요인의 경우 건청 성인이 인공와우이식 선천성 농 성인보다 높은 평균을 보였으나, 통계적으로 유의한차이는 보이지 않았다( $t=-1.770, p>.05)$. 이상의 연구 결과는 인공와우이식 선천성 농 성인은 건청 성인에 비해 전반적으로 낮은 $\mathrm{QCL}$ 을 보이며, 특히 의사소통 효능감, 일상생 활 참여, 의사소통 태도 측면에서 차이가 있음을 보여준다(Table 4).

\section{인공와우이식 선천성 농 성인의 의사소통 능력과 $\mathrm{QCL}$ 간 상관관계}

인공와우이식 선천성 농 성인의 의사소통 능력(단음절 단어검 사 점수, 이음절 단어검사 점수, 문장검사 점수, 수용어휘 점수, 조 음정확도)과 QCL 간의 상관관계 평가 결과, 의사소통 능력 중 단음 
Table 4. Descriptive statistics and $t$-test results of the $\mathrm{OCL}$ of participants with $\mathrm{Cl}$ and $\mathrm{NH}$

\begin{tabular}{lccc}
\hline & $\mathrm{Cl}$ & $\mathrm{NH}$ & \multicolumn{1}{c}{$t$} \\
\hline Total & $3.78(.46)$ & $4.17(.32)$ & $-2.926^{* *}$ \\
Communication efficacy & $3.17(.61)$ & $4.20(.40)$ & $-2.885^{* *}$ \\
Self-esteem and role & $3.77(.62)$ & $4.07(.40)$ & -1.770 \\
Participation in daily life & $3.82(.52)$ & $4.15(.39)$ & $-2.219^{*}$ \\
Communication attitude & $3.83(.46)$ & $4.25(.34)$ & $-3.152^{* *}$ \\
\hline
\end{tabular}

Values are presented as mean (SD).

$\mathrm{OCL}=$ quality of communication life scale; $\mathrm{Cl}=$ cochlear implant; $\mathrm{NH}=$ normal hearing ${ }^{*} p<.05,{ }^{* *} p<.01$.

Table 5. Descriptive statistics of communication abilities: prelingually deafened adults with $\mathrm{Cl}$

\begin{tabular}{lr}
\hline & \multicolumn{1}{c}{ Value } \\
\hline Monosyllabic word (\%) & $63.75(19.27)$ \\
Bisyllabic word (\%) & $80.46(23.89)$ \\
Sentence (\%) & $68.06(39.25)$ \\
Receptive vocabulary & $152.28(19.55)$ \\
Accuracy of articulation (\%) & $86.51(11.57)$ \\
\hline
\end{tabular}

Values are presented as mean (SD).

$\mathrm{Cl}=$ cochlear implant

절 $(r=.495, p<.05)$, 이음절 $(r=.549 p<.05)$, 문장 $(r=.545, p<.05)$ 의 듣기능력과 조음정확도 $(r=.479, p<.05)$ 와 $\mathrm{QCL}$ 간의 상관이 있 는 것으로 나타났다. 의사소통 능력 변인 간 관계는 단음절과 이음 절 $(r=.930, p<.01)$, 단음절과 문장 $(r=.911, p<.01)$, 단음절과 조음 정확도 $(r=.768, p<.01)$, 이음절과 문장 $(r=.973, p<.01)$, 이음절과 조음정확도 $(r=.797, p<.01)$, 문장과 조음정확도 $(r=.860, p<.01)$ 간에서 높은 상관이 확인되었다(Tables 5, 6).

\section{QCL에 대한 예측 변인}

인공와우이식 선천성 농 성인의 QCL을 예측할 수 있는 변인과 변인의 예측력을 살펴보기 위해 QCL 점수를 종속변수로 하고, 인 공와우이식 선천성 농 성인의 QCL과 상관이 있었던 단음절, 이음 절, 문장, 조음정확도를 독립변수로 다중회귀분석을 실시하였다. 모든 분석은 단계선택법(stepwise)을 사용한 다중회귀분석(multiple regression analysis) 방법을 사용하였다. 분석 결과, 듣기능력 중 이음절 듣기능력 요인이 QCL의 변화를 유의미하게 설명할 수 있었 으며 $(F=6.911, p<.05)$, 그 외 단음절, 문장듣기 능력, 조음정확도 는 회귀식에 유의한 영향을 주지 않는 것으로 나타났다. 이음절 듣 기능력은 QCL을 $30.2 \%$ (수정 결정계수는 25.8) 예측할 수 있는 것 으로 분석되었다(Table 7).
Table 6. Correlations between communication abilities and $\mathrm{OCL}$ : prelingually deafened adults with $\mathrm{Cl}$

\begin{tabular}{lccccc}
\hline & OCL & $\begin{array}{c}\text { Monosyl- } \\
\text { labic word }\end{array}$ & $\begin{array}{c}\text { Bisyllabic } \\
\text { word }\end{array}$ & Sentence & $\begin{array}{l}\text { Receptive } \\
\text { vocabulary }\end{array}$ \\
\hline Monosyllabic word & $.495^{*}$ & & & & \\
Bisyllabic word & $.549^{*}$ & $.930^{* *}$ & & & \\
Sentence & $.545^{*}$ & $.911^{* *}$ & $.973^{* *}$ & & \\
Receptive vocabulary & -.165 & .030 & .090 & .131 & \\
Accuracy of articulation $^{b}$ & $.479^{*}$ & $.768^{* *}$ & $.797^{* *}$ & $.860^{* *}$ & .129 \\
\hline
\end{tabular}

$\mathrm{QCL}=$ quality of communication life scale; $\mathrm{Cl}=$ cochlear implant.

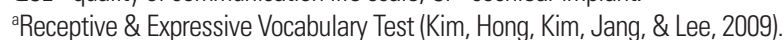

${ }^{\mathrm{b}}$ Assessment of Phonology and Articulation for Children (Kim, Pae, \& Park, 2007). ${ }^{*} p<.05,{ }^{* *} p<.01$.

Table 7. Stepwise multiple regression analysis with $\mathrm{QCL}$ as dependent variable

\begin{tabular}{lrrrrr}
\hline & \multicolumn{2}{c}{$\begin{array}{c}\text { Un-standardized } \\
\text { coefficients }\end{array}$} & $\begin{array}{c}\text { Standard- } \\
\text { ized coeffi- } \\
\text { cients }\end{array}$ & $t$ & $p$-value \\
\cline { 2 - 4 } & $\mathrm{B}$ & $\mathrm{SE}$ & .338 & 8.664 & .000 \\
\hline (constant) & 2.927 & .004 & .549 & 2.629 & .018 \\
Bisyllabic word & .011 & $.004), F=6.911, p=.018$ & \\
\hline
\end{tabular}

$\mathrm{OCL}=$ quality of communication life scale; $\mathrm{SE}=$ standard error. ${ }^{*} p<.05,{ }^{* *} p<.01$.

\section{논의 및 결론}

\section{$\mathrm{QCL}$ 의 하위요인별 집단 간 차이}

$\mathrm{QCL}$ 의 집단 간(인공와우이식 선천성 농 성인, 생활연령을 일치 시킨 건청 성인) 차이를 살펴본 결과, 인공와우이식 선천성 농 성인 의 QCL이 건청 성인에 비해 유의미하게 낮았고, 이는 청각장애인 과 건청인의 삶의 질에 유의한 차이가 있다는 선행연구의 결과와 일치한다(Choi, 2011; Jeong et al., 2013; Kim, 2014; Kim, 2017; Kim \& Jung, 2014a, 2014b; Lee \& Cho, 2011). 인공와우이식 선천성 농 성인이 건청 성인보다 낮은 QCL을 보인 이유는 청력손실로 인한 타인과의 의사소통 단절이 일상과 사회생활의 삶에 미치는 부정적 인 영향에서 기인한다고 볼 수 있다. 또한, 성인기는 학업 및 취업에 따른 대인관계의 폭이 확장되는 시기로, 타인과의 효율적인 의사소 통을 할 수 없을 때 이전 시기보다 더 큰 제약을 겪게 될 수 있다. 특 히, QCL의 하위요인 중 의사소통 효능감, 일상생활 참여, 의사소통 태도 요인에서 인공와우이식 선천성 농 성인이 건청 성인보다 유의 미하게 낮은 점수를 보였다. 이는 Kim (2017)의 연구결과와 일치하 며, 청각장애인들의 의사소통 단절이 대인관계 유지에 어려움을 유 발하여 교육환경 및 일상생활에서의 참여에 제약을 미치는 것이 원인이라 볼 수 있다. QCL 하위요인 중 자아존중 및 역할은 집단 
간의 유의미한 차이가 나타나지 않았는데, 해당 설문 문항이 다른 하위요인 문항보다 타인과 의사소통하는 상황이 아닌 독립된 개체 로 자신을 판단할 수 있는 문항으로 구성되어 있기 때문인 것으로 판단된다(Kim, 2017).

\section{인공와우이식 선천성 농 성인의 의사소통 능력과 QCL 간 상관관계}

인공와우이식 선천성 농 성인의 의사소통 능력과 $\mathrm{QCL}$ 간의 상 관관계 분석 결과, 수용어휘를 제외하고 듣기능력(단음절, 이음절, 문장)과 조음정확도가 QCL과 상관이 있는 것으로 나타났다. 또한 의사소통 능력의 변인 간 관계에서도 수용어휘를 제외하고 듣기능 력(단음절, 이음절, 문장) 내 변수 간에 모두 높은 상관관계를 보였 고, 조음정확도와 듣기능력 간에도 높은 상관관계를 보였다. 이는 조음정확도는 포함되어 있지 않지만, 듣기능력과 QCL 간에 유의미 한 상관이 있다는 Kim (2017)의 연구결과와 일치한다. QCL에 중요 한 영향을 미치는 듣기능력은 선행연구에서도 삶의 질과 관련하여 다음과 같이 다양하게 보고된다. Kim (2014)에서는 청각장애 아동 이 건청 아동과 비교했을 때 낮은 QCL을 보였고, 청각장애 아동의 청력손실을 일차적인 문제로 언급하였다. 청각장애 성인 집단에서 도 듣기능력이 QCL에 유의미한 영향을 미치며(Kim, 2017), 노인 집단에서도 청력손실이 큰 집단에서 의사소통의 어려움으로 낮은 삶의 질을 보였다(Dalton et al., 2003). 즉, 청각장애인은 아동기부 터 청력손실로 인한 듣기능력 저하로 의사소통의 어려움을 지속적 으로 경험하고, 이후 성인이 되어서도 QCL에 부정적인 영향을 받 는 것으로 볼 수 있다. 또한 본 연구에서는 조음정확도와 $\mathrm{QCL}$ 간의 유의미한 상관관계를 확인하였다. 조음정확도는 말명료도와 관련 이 있고, 청각장애인들은 자음과 모음의 조음오류 및 생략, 왜곡 등 으로 인해 낮은 말명료도를 보인다. 이는 의사소통의 단절을 유발 하고 삶의 질에 부정적인 영향을 미치므로, 조음정확도와 $\mathrm{QCL}$ 간, 조음정확도와 듣기능력 간의 유의미한 상관관계를 이해할 수 있다.

\section{$\mathrm{QCL}$ 관련 변인의 예측력}

$\mathrm{QCL}$ 과 높은 상관을 보인 듣기능력(단음절, 이음절, 문장)과 조 음정확도의 예측력을 분석한 결과, 듣기능력 중 이음절 듣기점수가 QCL의 예측 변인으로 나타났고, $30.2 \%$ (수정 결정계수는 25.8)의 예측력을 보였다. 이는 듣기능력이 QCL을 예측할 수 있다는 Kim (2017)의 연구결과와 일치하며, 인공와우이식 선천성 농 성인도 듣 기능력이 좋을수록 다양한 상황에서 성공적인 구어적 의사소통이 가능하여 전반적인 삶의 질을 높일 수 있다고 사료된다. 단음절이 나 문장이 아닌 이음절 듣기능력이 예측 변인으로 분석된 것은 이
음절 단어는 일음절 단어검사보다 말소리 정보가 더 많이 제공되 는 어휘적 특성이 있고, 문장은 일상생활에서 사용하는 언어에 가 장 가깝지만 문장 길이, 화자의 말 속도, 재활 시작 시기, 구문 능력, 청각정보 처리능력 등과 같은 요인에 영향을 많이 받는다는 점을 고려하여 설명할 수 있다. 청각장애인의 듣기능력은 검사도구에서 제시된 말소리 자극의 형태가 어떤 단위를 갖고 있는가에 따라 다 르게 나타나며(Yoon, Sim, Chang, \& Kim, 2005), 이음절 단어 듣기 는 말지각 시 제대로 듣지 못했던 소리를 자신이 알고 있는 단어들 중 유사한 소리의 단어로 선택할 수 있다는 점에서 유리하다.

연구결과를 정리하면, 인공와우이식 선천성 농 성인은 건청 성인 에 비해 낮은 QCL을 보이며, 의사소통 능력 중에서 듣기능력(단음 절, 이음절, 문장)과 조음정확도가 QCL과 상관관계를 가지는 것 으로 확인되었다. 특히 이음절 듣기능력을 통해 QCL을 $30 \%$ 정도 예측할 수 있는 것으로 분석되었다. 이는 인공와우이식 선천성 농 청각장애인의 경우 $\mathrm{QCL}$ 의 향상을 위해 아동기뿐만 아니라 성인기 가 되어서도 듣기능력 및 말산출 능력을 향상시킬 수 있는 청능재 활 프로그램과 중재활동에 참여할 필요성이 있다는 임상적 시사점 을 제시한다. 또한, 청능재활을 담당하는 언어장애전문가는 대상 자의 $\mathrm{QCL}$ 측정을 통해 효율적인 개별 중재 프로그램을 제공하여 성공적인 의사소통에 도움을 줄 수 있을 것임을 의미한다. 단, 본 연 구의 대상자가 각각 그룹별 18 명으로 제한적이며, 성별이나 인공와 우이식 연령 및 사용 기간에 제한을 두지 않았으므로, 대상자의 배 경변인을 통제하지 못한 것은 본 연구의 제한점이라 밝힌다.

\section{REFERENCES}

Bandura, A. (1977). Self-efficacy: toward a unifying theory of behavioral change. Psychological Review, 84, 191-215.

Bose, A., McHugh, T., Schollenberger, H., \& Buchanan, L. (2009). Measuring quality of life in aphasia: results from two scales. Aphasiology, 23, 797-808.

Choi, D. H. (2003). The relationship between communication attitude and stuttering severity of stuttering adults (Master's thesis). Ewha Womans University, Seoul, Korea.

Choi, H. Y. (2011). Development of the quality of life scale: Korean version (Master's thesis). Yonsei University, Seoul, Korea.

Clark, M. (1989). Language through living for hearing-impaired children. London: Hodder and Stoughton.

Dalton, D. S., Cruickshanks, K. J., Klein, B. E., Klein, R., Wiley, T. L., \& Nondahl, D. M. (2003). The impact of hearing loss on quality of life in older adults. The Gerontologist, 43, 661-668. 
Heo, M. J., \& Kim, L. S. (2010). School performance of children received cochlear implantation under age of five. Journal of Special Education: Theory and Practice, 11, 306-337.

Jeong, S. Y., Lim, K. W., \& Kim, S. S. (2013). Comparison of the quality of communication life between the physically disabled, the hearing impaired and without disabilities. Journal of Rehabilitation Research, 17, 279-297.

Kim, D. H. (2017). The effect of speech intelligibility of patients with Parkinson' disease on quality of communication life (Master's thesis). Korea Nazarene University, Cheonan, Korea.

Kim, D. I. (2008). Basic Academic Skills Assessment (BASA): reading. Seoul: Hakjisa.

Kim, M. J., Pae, S., \& Park, C. I. (2007). Assessment of Phonology and Articulation for Children $(A P A C)$. Incheon: Human Brain Research \& Consulting Co.

Kim, S., Jung, H. Y., Na, K. S., Lee, S. I., Kim, S. G., Lee, A. R., \& Cho, J. T. (2014). A validation study of the Korean version of Warwick-Edinburgh mental well-being scale. Journal of Korean Neuropsychiatric Association, 53, 237-245.

Kim, T. G. (2014). Development of communication-related quality of life scale for children with hearing impairment (Doctoral dissertation). Chosun University, Gwangju, Korea.

Kim, T. G., \& Jung, E. H. (2014a). A study on communication-related quality of life for children with hearing impairment. Journal of Special Education: Theory and Practice, 15, 93-110.

Kim, T. G., \& Jung, E. H. (2014b). Development of communication-related quality of life scale for children with hearing impairment. Korea Journal of Special Education, 49, 49-70.

Kim, Y. H. (2016). A comparison of students with hearing disabilities using sign language and students with hearing disabilities using oral language in self-identity, self-efficacy, and quality of life (Master's thesis). Woosuk University, Jeollabuk-do, Korea.

Kim, Y. T., Hong, G. H., Kim, K. H., Jang, H. S., \& Lee, J. Y. (2009). Receptive \& expressive vocabulary test (REVT). Seoul: Seoul Community Rehabilitation Center.

Lee, J. H., Cho, S. J., Kim, J. S., Jang, H. S., Lim, D. H., Lee, K. W., \& Kim, H. J. (2010). Korean speech audiometry (KSA). Seoul: Hakjisa.

Lee, J. W. (2014). A study on the relationships between hearing-impaired students' self-identity, their self-efficacy, and their recognition of communication styles (Doctoral dissertation). Daegu University, Gyeongsan, Korea.

Lee, J. Y. (1999). A survey of the citizen's quality of life in the city of Taegu by WHOQOL-BREF (Master's thesis). Keimyung University, Daegu, Korea.
Lee, M. S., \& Cho, S. J. (2011). A study on the quality of life (QoL) in hearing impaired students. Journal of Rehabilitation Research, 15, 175-187.

Markham, C., Van Laar, D., Gibbard, D., \& Dean, T. (2009). Children with speech, language and communication needs: their perceptions of their quality of life. International Journal of Language \& Communication Disorders, 44, 748-768.

Park, J. W., \& Kwon, D. H. (2009). A research on psychological and emotional communication attitude of school-aged children with stutter. Journal of Emotional \& Behavioral Disorders, 25, 39-56.

Park, K. E. (2012). The effect of speech intelligibility of patients with Parkinson' disease on quality of communication life (Master's thesis). Yonsei University, Seoul, Korea.

Park, S. H. (2002). Development of quality of life scale for Korean with disability. Korea Journal of Special Education, 37, 41-78.

Park, S. I. (2015). Development of the scale for quality of life in adult and elder with hearing loss (QOL-AEHL) (Doctoral disseration). Hallym University, Chuncheon, Korea.

Paul, D. R., Frattali, C. M., Holland, A. L., Thompson, C. K., Caperton, C. J., \& Slater, S. C. (2004). Quality of communication life scale (ASHA QCL). Rockville, MD: American Speech-Language-Hearing Association.

Teoh, S. W., Pisoni, D. B., \& Miyamoto, R. T. (2004). Cochlear implantation in adults with prelingual deafness. Part I. Clinical results. Laryngoscope, 114, 1536-1540.

The WHOQOL Group. (1995). The World Health Organization quality of life assessment (WHOQOL): position paper from the World Health Organization. Social Science \& Medicine, 41, 1403-1409.

Whyte, A. K., \& Guiffrida, D. A. (2008). Counseling Deaf college students: the case of Shea. Journal of College Counseling, 11, 184-192.

Yoon, M. S. (2007). A qualitative study of the evaluation of communication abilities in the diagnosis of children with hearing impairment. Korean Journal of Communication \& Disorders, 12, 447-464.

Yoon, M. S., Sim, H. S., Chang, S. O., \& Kim, C. S. (2005). Predictor variables of speech intelligibility after cochlear implant in Korean prelingually deafened children. Korean Journal of Communication \& Disorders, 10, 57-70.

Yoon, M., Lee, Y., \& Sim, H. S. (2000). The relationship between speech intelligibility and related factors of speakers in prelingually hearing impaired children using hearing aids. Korean Journal of Communication \& Disorders, 5, 144-158. 
Appendix 1. 의사소통 삶의질 요인 및 문항

\begin{tabular}{|c|c|c|}
\hline 요인 & 번호 & 문항 \\
\hline \multirow{8}{*}{ 의사소통 효능감 } & 1 & 나는 다른 사람과 대화하는 것이 쉽다. \\
\hline & 2 & 나는 학교와 직장, 사회생활에서 필요한 구어 의사소통이 자유롭다(예. 발표하기, 질문하기, 읽기 등). \\
\hline & 3 & 나는 스스로 결정을 내린다. \\
\hline & 4 & 나는 낯선 사람(예. 잘 모르는 사람)과의 대화에 자신이 있다. \\
\hline & 5 & 나는 내 의견을 스스로 말할 수 있다(예. 팀 과제에서 내 의견을 말한다). \\
\hline & 6 & 나는 다른 사람에게 먼저 말을 걸 수 있다. \\
\hline & 7 & 나는 물건을 살 때 필요한 내용을 직접 점원에게 물어볼 수 있다. \\
\hline & 8 & 나는 식당에서 말로 음식을 주문할 수 있다. \\
\hline \multirow[t]{9}{*}{ 자아존중 및 역할 } & 1 & 나는 집에서 내 역할을 알고 행동한다(예. 부모/자식으로서의 역할. 형, 누나, 동생으로서의 역할). \\
\hline & 2 & 나는 일상생활이 즐겁다. \\
\hline & 3 & 나는 가정, 학교/직장 생활에서 필요한 사람이라고 느낀다. \\
\hline & 4 & 나는 사랑받고 있다고 느낀다. \\
\hline & 5 & 나는 친구에게 나의 고민과 비밀을 이야기 할 수 있다. \\
\hline & 6 & 나는 내 자신을 자랑스럽게 생각한다. \\
\hline & 7 & 나는 일/과제에 실패해도 다음에는 성공할 수 있다고 자신을 격려한다. \\
\hline & 8 & 나는 내가 좋은 사람이라고 생각한다. \\
\hline & 9 & 나는 다른 사람들과 잘 사귈 수 있다. \\
\hline \multirow[t]{9}{*}{ 일상생활 참여 } & 1 & 나는 친구/친척과 연락하면서 지낸다. \\
\hline & 2 & 나는 사람들 대화에 같이 참여할 수 있다. \\
\hline & 3 & 나는 영화와 TV(예. 뉴스, 운동경기, 드라마)의 내용을 이해한다. \\
\hline & 4 & 나는 윗사람(예. 부모님, 선생님, 직장 상사, 선배 등)이 시킨 일을 이해하고 행동한다. \\
\hline & 5 & 나는 취미생활을 즐긴다. \\
\hline & 6 & 나는 외부 활동(예. 스포츠, 축제, 공연관람, 영화관람 등)에 참여한다. \\
\hline & 7 & 나는 새로운 일에 흥미를 가지고 참여한다. \\
\hline & 8 & 나는 사람들에게 도움을 청할 수 있다. \\
\hline & 9 & 나는 자신의 능력 증진에 도움이 되는 활동(예. 학원, 언어치료 등)에 지속적으로 참여한다. \\
\hline \multirow[t]{9}{*}{ 의사소통 태도 } & 1 & 나는 사람들과 대화하는 것을 좋아한다. \\
\hline & 2 & 사람들은 내가 한 말을 잘 알아듣는다. \\
\hline & 3 & 사람들이 내 말을 잘 알아듣지 못할 때, 내 말을 이해시키기 위해서 노력한다. \\
\hline & 4 & 나는 다른 사람들의 이야기를 잘 들어준다. \\
\hline & 5 & 나는 궁금한 것이 있으면 망설이지 않고 타인(예. 다른 사람)에게 질문을 할 수 있다. \\
\hline & 6 & 나는 친구/동료의 실수를 위로하고 격려해 줄 수 있다. \\
\hline & 7 & 나는 다른 사람에게 친절하게 대할 수 있다(예. 사람들이 길을 물어볼 때 등). \\
\hline & 8 & 나는 대화시 발생하는 문제에 잘 대처한다(예. 상대방이 나의 말을 잘못 이해했을 경우, 다시 설명하여 해결할 수 있다) \\
\hline & 9 & 나는 사람들이 나에게 질문을 하면 당황하지 않고 대답할 수 있다. \\
\hline
\end{tabular}




\section{국문초록}

\section{인공와우이식 선천성 농 성인의 의사소통 관련 삶의 질}

이슬기 ${ }^{1} \cdot$ 정상임 $^{2} \cdot$ 탁평곤 $^{2} \cdot$ 이수복 $^{2} \cdot$ 이영미 $\left.\right|^{3}$

'동아와우청각언어센터, ${ }^{2}$ 우송대학교 언어치료청각재활학과, ${ }^{3}$ 동명대학교 언어치료학과

배경 및 목적: 청각장애인들은 부족한 의사소통 능력으로 인해 인간관계에서 끊임없이 좌절을 경험하고, 사회 적응에 여러 제약을 받 아 건청인과 비교하여 상대적으로 낮은 삶의 질을 보인다. 본 연구는 인공와우이식을 받은 선천성 농 성인과 건청 성인 간의 의사소통 관련 삶의 질(quality of communication life, $\mathrm{QCL}$ )을 비교하여 QCL의 하위요인별(의사소통 효능감, 자아 존중 및 역할, 일상생활 참여, 의사소통 태도) 차이를 파악하고, 그들의 의사소통 능력(단음절 단어검사의 음소점수, 이음절 단어검사의 음소점수, 문장검사 단어점 수, 조음정확도, 수용어휘 점수) 중 QCL을 예측할 수 있는 변인을 알아보고자 하였다. 방법: 만 19-39세의 인공와우이식 선천성 농 성인 18 명과 생활연령을 일치시킨 건청 성인 18 명을 대상으로 QCL에 대한 설문을 진행하였고, 인공와우이식 선천성 농 성인의 의사소통 능 력을 평가하였다. QCL의 하위요인에 따라 집단 간의 유의한 차이가 있는지를 살펴보기 위해 $t$-검정을 실시하였고, 의사소통 능력과 인 공와우이식 선천성 농 성인의 QCL 간의 관계를 살펴보기 위해 피어슨 상관분석을 실시하였다. 또한 인공와우이식 선천성 농 성인의 QCL에 대한 예측 변인을 알아보고자 다중회귀분석을 실시하였다. 결과: 인공와우이식 선천성 농 성인의 QCL은 건청 성인에 비해 유 의하게 낮았고, QCL의 하위요인별 분석에서는 ‘의사소통 효능감’, ‘일상생활 참여’, ‘의사소통 태도'에서 인공와우이식 선천성 농 성인의 점수가 유의하게 낮게 나타났다. 또한, 의사소통 능력 중 듣기능력(단음절, 이음절, 문장)과 조음정확도가 QCL과의 상관을 보였으며, 그 중 이음절 듣기능력이 QCL에 대한 $30 \%$ 정도의 예측력을 보였다. 논의 및 결론: 인공와우이식을 받은 청각장애인은 성인이 되어서 도 듣기능력과 말산출 능력 향상을 위한 중재를 꾸준히 받는 것이 QCL을 향상시키고, 궁극적으로 전반적인 삶의 질을 증진시킬 수 있 음을 시사한다. 또한 언어장애전문가는 QCL 측정을 통해 더 효율적인 개별 중재 프로그램을 제공할 수 있는 근거 자료를 확보할 수 있 다.

핵심어: 인공와우이식, 선천성 농 성인, 의사소통 관련 삶의 질, $\mathrm{QCL}$, 의사소통 능력

본 논문은 제 1 저자의 석사학위논문(2018)을 일부 발췌하여 수정·보완한 것임.

\section{참고문헌}

김다혜(2017). 청각장애 대학생의 의사소통 삶의 질. 나사렛대학교 대학원 석사학위논문.

김동일(2008). 기초학습기능 수행평가체제: 읽기검사. 서울: 학지사.

김민정, 배소영, 박창일(2007). 아동용 발음평가(APAC). 인천: 휴브알앤씨.

김세웅, 정한용, 나경세, 이소영, 김신겸, 이아름, 조준택(2014). 한국판 WEMWBS의 타당화 연구. 신경정신의학, 53, 237-245.

김영태, 홍경훈, 김경희, 장혜성, 이주연(2009). 수용·표현어휘력검사(REVT). 서울: 서울장애인종합복지관.

김윤희(2016). 구화와수화사용 청각장애중등학생의 자아정체감, 자기효능감 및 삶의 질 비교. 우석대학교 대학원 석사학위논문.

김태강(2014). 청각장애아동의 의사소통 관련 삶의 질 측정도구 개발. 조선대학교 대학원 박사학위논문.

김태강, 정은희(2014b). 청각장애아동의 배경변인 및 청각장애아동과 건청아동 간의 의사소통 관련 삶의 질 연구. 특수교육저널: 이론과 실천, 15, 93-

110.

김태강, 정은희(2014b). 청각장애아동의 의사소통 관련 삶의 질 측정도구 개발 연구. 특수교육학연구, 49, 79-70.

박경은(2012). 파킨슨병 환자의 말명료도가 의사소통 삶의 질에 미치는 영향. 연세대학교 대학원 석사학위논문.

박성일(2015). 청각장애 장노년기의 삶의 질 척도 개발. 한림대학교 대학원 박사학위논문. 
박승희(2002). 한국 장애인의 삶의 질 측정도구 개발 연구. 특수교육학연구, 37,41-78.

박진원, 권도하(2009). 학령기 말더듬아동의 심리적 정서적 의사소통 태도에 관한 연구. 정서·행동장애연구, 25, 39-56. 윤미선(2007). 청각장애 아동의 진단과 평가 시 의사소통능력 평가의 중요성에 관한 질적 연구. 언어청각장애연구, 12, 447-464.

윤미선, 심현섭, 장선오, 김종선(2005). 선천성 심도 청각장애 아동의 와우이식 후 말명료도 예측 변인. 언어청각장애연구, 10, 57-70. 윤미선, 이윤경, 심현섭(2000). 청각장애아동의 말명료도에 영향을 미치는 화자 요인. 언어청각장애연구, 5, 144-158.

이미숙, 조수진(2011). 청각장애 학생들의 삶의 질에 관한 연구. 재활복지, 15, 175-187.

이정우(2014). 청각장애대학생의 자아정체감, 자기효능감, 의사소통양식 간의 관계 연구. 대구대학교 대학원 박사학위논문. 이정학, 조수진, 김수진, 장현숙, 임덕환, 이경원, 김형종(2010). 어음청각검사(Korean speech audiometry). 서울: 학지사. 이종렬(1999). WHOQOL-BREF를 이용한 대구광역시민의 삶의 질에 관한 조사. 계명대학교 대학원 석사학위논문. 정소영, 임경원, 김삼섭(2013). 지체장애인, 청각장애인 및 일반인의 의사소통 삶의 질 비교. 재활복지, 17, 279-297. 최다혜(2003). 말더듬 성인의 말더듬 정도와 의사소통태도 간 상관 연구. 이화여자대학교 대학원 석사학위논문. 최혜윤(2011). 의사소통 삶의 질 척도의 한국어판 번안. 연세대학교 대학원 석사학위논문. 허민정, 김리석(2010). 인공와우이식 아동의 학교 수행력: 5 세 이전에 수술 받은 아동을 중심으로. 특수교육저널: 이론과 실전, 11, 306-337. 